\title{
Henoch-Schonlein purpura due to sodium valproate: A Case report
}

mojgan safari ${ }^{1}$ and firozeh hosseini ${ }^{1}$

${ }^{1}$ Hamadan University of Medical Sciences

December 22, 2021

\begin{abstract}
The etiology of Henoch-Schönlein purpura (HSP) has been frequently attributed to certain drugs. Anticonvulsive drugs are reported rarely in drug-induced HSP.We report a 5-year-old girl with a seizure treated with sodium valproate. we report a case of HSP due to the consumption of sodium valproate.
\end{abstract}

\section{Hosted file}

ArticleX2.docx available at https://authorea.com/users/452192/articles/550322-henochschonlein-purpura-due-to-sodium-valproate-a-case-report 